\title{
A DELICADEZA DO GOSTO E A FORMAÇÃO ESTÉTICA EM HUME
} THE DELICACY OF TASTE AND THE AESTHETIC TRAINING IN HUME LA DELICADEZA DEL GUSTO Y LA FORMACIÓN ESTÉTICA EN HUME

\author{
Josivan Moura de Sá \\ Pós-Graduado em Docência do Ensino Superior (Uniasselvi - Indaial/SC). \\ Servidor Público Federal da Controladoria Regional da União no Estado do Maranhão. \\ josivanmouradesa@bol.com.br
}

Almir Ferreira da Silva Júnior Professor Doutor da Universidade Federal do Maranhão (UFMA). alferjun@uol.com.br

\begin{abstract}
RESUMO: O presente artigo discute a importância da "Delicadeza do Gosto" como fundamento para o "Padrão do Gosto" na perspectiva de refletir acerca dos fundamentos estéticos da educação. Sendo o gosto uma expressão da natureza humana, em que medida o mesmo pode ser educado e formado socialmente? Traça um apanhado histórico sucinto de como a questão do gosto se apresentou ligado a cânones estéticos desde a antiguidade até a época em que viveu Hume. Explicita como a questão do Gosto passou de uma posição de menor prestígio no seio das discussões filosóficas, atingindo patamares elevados e mostrando-se capaz de abalar posicionamentos tradicionalmente aceitos no que se refere às questões estéticas. Explicita os argumentos humeanos contrapostos às concepções estéticas de sua época (objetivismo tradicional e subjetivismo). Fundamenta a interpretação de que o "Padrão do Gosto", no pensamento humeano, escapa à mera agradabilidade, não promove o estabelecimento de uma aristocracia estética, e consequentemente se constitui um elemento primordial no desenvolvimento da formação humana.
\end{abstract}

PALAVRAS-CHAVE: Gosto. Delicadeza do gosto. Padrão do gosto. David Hume. Estética. Formação estética.

ABSTRACT: This article discusses the importance of "Delicacy of Taste" as a basis for the "Standard of Taste" with a view to reflect on the aesthetic foundations of education. Like an expression of human nature, to what extent it can be educated and trained socially? It presents a brief historical overview of how the question of taste is presented on the aesthetic canons from antiquity to the time in which Hume lived. It sets out how the issue of Taste went from a less prestigious position within the philosophical discussions, reaching high levels and proving to be able to shake positions traditionally accepted with regard to aesthetic issues. Article explains Hume's arguments that oppose the aesthetic conceptions of his time (traditional subjectivism and objectivism). Based in interpretation of the "Standard of Taste" in Humean thought, escapes mere pleasantness, does not promote the establishment of an aesthetic aristocracy, and consequently constitutes a key element in the development of human formation.

KEYWORDS: Taste. Delicacy of taste. Standard of taste. David Hume. Aesthetics. Aesthetic training.

RESUMEN: El presente artículo discute la importancia de la "Delicadeza del Gusto" como fundamento para el "padrón del gusto" en la perspectiva de reflexionar sobre los fundamentos estéticos de la educación. ¿Siendo el gusto una expresión de la naturaleza humana, en qué medida puede ser educados y formado socialmente? Rastrea una reseña histórica de cómo la cuestión de gusto se presentó conectado a los cánones estéticos desde la antigüedad hasta la época en que vivió Hume. Establece cómo la cuestión del Gusto pasó de una posición de menor prestigio dentro de las discusiones filosóficas, alcanzando niveles altos y mostrándose capaz de mover posiciones tradicionalmente aceptadas con respecto a las cuestiones estéticas. Explicita los argumentos humanos se oponen a las concepciones estéticas de su tiempo (objetivismo tradicional y subjetivismo). Fundamenta la interpretación de que el "Padrón del Gusto" en el pensamiento de humano, escapa a la mera simpatía, no promueve el establecimiento de una aristocracia estético, y por lo tanto constituye un elemento esencial en el desarrollo de la formación humana. PALABRAS CLAVE: Gusto. La Delicadeza del Gusto. Padrón del Gusto. David Hume. Estética. Formación Estética.

Artigo recebido em setembro de 2015

Aprovado em novembro de 2015

Cad. Pes., São Luís, v. 22, n. 3, set./dez. 2015 


\section{1 | INTRODUÇÃO}

A educação é um fenômeno plural seja pelas múltiplas relações que o seu processo estabelece com o mundo, seja pela natureza pluridimensional daquilo que constitui a sua especificidade: a condição humana. Daí as mais diversas vertentes que possibilitam pensar sua dinâmica em sua relação direta com o mundo da vida social, econômico, ético-político e intercultural em seus distintos domínios de conhecimento, dentre eles o filosófico; e, de modo mais específico, aquele que contempla os denominados "fundamentos estéticos da educação"1. Como sabemos, a educação é um fenômeno humano cuja reflexão traduz o conjunto de comportamentos e idealizações da existência em sociedade, registrando em sua dinâmica interpretações, julgamentos e transformações decorrentes da singularidade de sua própria natureza na construção do mundo da cultura. Assim, é no exercício de suas faculdades do sentir, do pensar e da ação que a existência constrói um mundo eminentemente humano e intersubjetivo repleto de sentido e significado, no qual sobressaem as manifestações do sentimento de gosto e as expressões da beleza, oriundas da natureza e das artes. Eis o que possibilita uma relação entre educação e estética, o que por vezes se enuncia sob a expressão "dimensão estética da educação", cujo universo de investigação contempla um olhar mais atento à educação da sensibilidade e dos sentimentos, bem como à formação do gosto, e o cultivo da beleza como uma experiência subjetiva, ética, política e cultural.

Nessa perspectiva, o propósito deste artigo é apresentar uma reflexão estética do gosto como elemento da formação humana e que não se restringe a uma expressão eminentemente subjetiva e particular. Para tanto, toma-se como fundamentação teórica a filosofia do pensador escocês David Hume, e mais delimitadamente sua análise sobre o desenvolvimento do sentimento de "Delicadeza" (Delicacy of Taste) como fundamento para pensarmos o "Padrão do Gosto (Standard of Taste) inerente à natureza humana. Tais elementos conceituais promovem, assim, a possibilidade de pensarmos a relação entre gosto e educação, ou mesmo a importância do gosto no desenvolvimento de uma educação estética dos seres humanos.

O pensamento estético humeano está disperso em vários ensaios filosóficos. Um dos principais é "Do Padrão do Gosto" (Of the Standard of Taste,1757)2, obra em que apresenta a categoria que dá nome ao próprio ensaio e que servirá como resposta a um problema que ganhará força a partir do século XVII, ou seja, saber se o Belo é sentimento subjetivo ou objetivo. Outro ensaio fundamental, do mesmo filósofo, é a "Da Delicadeza do Gosto e da Paixão" (Of the Delicacy of Taste and Passion, 1757). Ambos se evidenciarão de extrema importância para a construção do presente artigo.

Na época em que viveu Hume, o debate entre as vertentes subjetivista e objetivista, no cenário das reflexões estéticas, ainda era vigente. Segundo Bastos (1986, p. 48), de um lado, defendiam a vertente subjetivista grandes pensadores da Modernidade, tal como Thomas Hobbes, renomado filósofo empirista; do outro, conforme atesta Cassirer (1997, p. 373), como defensores da corrente objetivista, havia nomes de igual peso, a exemplo de Boileau, cuja obra teria elevado a Estética ao patamar de uma exatidão científica.

\footnotetext{
1 Tal expressão é título do livro de João Francisco Duarte Junior, publicado pela primeira vez em 1988 e com edições atualizadas até hoje. Seu propósito é uma reflexão que se tornou clássica e que contempla a relação entre a experiência estética e a educação considerando o processo do conhecimento a partir das esferas do sentir e do simbolizar. Desse modo, formam-se os jogos culturais, a concretização e transmissão dos significados, elementos indispensáveis para pensarmos a relação entre cultura e educação em uma perspectiva intercultural.

2 O ensaio foi publicado inicialmente em 1757 integrando o volume Quatro Dissertações, ao lado de Historia natural das religião, Dissertação sobre as Paixões e Da Tragédia. Posteriormente em uma edição de 1758, Sobre o Padrão do Gosto e Da Tragédia foram incorporados em Ensaios Morais, Políticos e Literários.
} 


\section{A DELICADEZA DO GOSTO | Josivan Moura de Sá e Almir Ferreira da Silva Júnior}

Sabe-se que Hume sucede temporalmente a Hobbes e recebe considerável influência do empirismo inglês. Sem falar que a tendência subjetivista ainda se fazia fortemente presente no século XVIII, o que poderia fazer pensar que o filósofo escocês enveredaria pela defesa da aludida vertente em relação às questões do "Gosto", aceitando os juízos estéticos como juízos marcadamente particulares, simplesmente agradáveis.

Todavia, Osborne (1978, p. 150) esclarece que Hume, contrariando os apelos subjetivistas, lança-se em busca do "Padrão do Gosto", mesmo admitindo a existência de certa variedade de gostos no mundo. Hume tinha ciência de que seu empreendimento seria um trabalho árduo, já que significava abalar os fundamentos científicos e metafísico-teológicos vigentes à sua época, enclausurados em seus palácios de arrogância. Enfrentaria a vertente do subjetivismo estético, sem, no entanto, enveredar pela exatidão objetivista moderna. O problema que então se colocava e permanece em suas ressonâncias na atualidade é: em que medida o fenômeno do gosto não está limitado ao relativismo de sua variedade subjetiva e, do ponto de vista filosófico, reivindica um critério objetivo e social expresso pelo padrão do gosto? E a este se acrescenta: qual a importância de uma reflexão sobre o gosto como elemento de formação humana e construção ético-cultural?

Entretanto, a supracitada empreitada é interpretada como uma tentativa vã de escapar à corrente subjetivista. Luc Ferry, renomado filósofo francês, por exemplo, defende que, no pensamento de David Hume, o juízo estético (o Belo) consiste em um juízo agradável, além de considerar o "Padrão do Gosto" humeano como uma proposta de aristocratização estética, ou seja, de uma elite especializada em determinar o Belo ou não. Não obstante, embora se reconheça alguma consistência nas críticas traçadas por Luc Ferry, julga-se ser possível sustentar, na estética humeana, uma interpretação diferente da estabelecida pelo mencionado filósofo francês.

Com efeito, Hume fundamenta o "Padrão do Gosto" a partir de outra categoria que se mostra como essencial para a compreensão do aludido conceito. Trata-se da "Delicadeza do Gosto", que se pode depreender das seguintes palavras: "Embora sejam raros os homens de gosto delicado, é fácil distingui-los na sociedade, pela solidez de seu entendimento e pela superioridade de suas faculdades sobre as do resto da humanidade" (HUME, 1973, p. 322).

A referida delicadeza, no pensamento humeano, parece sugerir o florescimento de uma relação autêntica dos homens com a Arte, não ficando mais esta subordinada a elementos estranhos ao seu próprio âmago. Por meio da "Delicadeza do Gosto", o sentimento do Belo possibilita o resplandecer da natureza humana, lembrando que a medida do humano somente é atingida com o brilho do Belo.

Dessa forma, em vista da possibilidade de oposição salutar de interpretações acerca da filosofia de Hume, ratifica-se uma interrogação que também nos inspira para a elaboração do presente artigo: seria possível a "Delicadeza do Gosto" se apresentar como fundamento ao "Padrão do Gosto", no pensamento do aludido filósofo, contrapondo-se às concepções estéticas modernas, mas sem que se caracterize como uma aristocracia estética?

Como se vê, o problema acima se mostra merecedor de investigação, haja vista que o pensamento estético humeano, por sua complexidade, apresenta-se sujeito a interpretações divergentes. Sem falar que, nos meios acadêmicos, a referida questão ainda se mostra aberta a bastantes reflexões. Como até agora a ênfase dada é, sobretudo registrando o fracasso dessa proposta filosófica empirista, com a presente pesquisa, objetiva-se apresentar uma leitura diferenciada de como o referido filósofo equacionou o problema de sua época referente à questão do "Gosto", além de contribuir significativamente para a discussão acerca do caráter estético-educacional da formação do gosto. 


\section{2 | O GOSTO: uma questão filosófica}

Desde a Antiguidade Clássica, perpassando pelos períodos Medieval e Renascentista, e prolongando-se até os séculos XVII e XVIII, a questão do "Gosto" se mostrava obscurecida pelas concepções estéticas vigentes em cada momento, concepções estas que enquadravam o sentimento do Belo a critérios ora matemáticos, ora teológicos, ou mesmo uma verdade objetiva; ou ainda como uma questão inferior, uma simples distração da Razão, não agregando maiores preocupações às esferas filosóficas, científicas ou mesmo teológico-metafísicas dos respectivos momentos.

Entretanto, o fenômeno do "Gosto", a partir do século XVIII, passou por uma reconfiguração, apresentando-se como um problema efetivamente estético-filosófico. A referida questão trouxe sérias repercussões às instâncias filosóficas, científicas e teológico-metafísicas da época.

Até o século XVIII, o acesso ao Belo era tratado pelas vias racionais ou da fé, ou seja, pelas vias extra-sensoriais, extra-corpóreas, exceto na concepção que tinha o aludido sentimento como uma modalidade de divertimento imaginativa, em que se pregava a impossibilidade de qualquer acesso racional ao mesmo. Em todo caso, tais concepções passavam a mensagem à Filosofia, de que a mesma não deveria desenvolver maiores preocupações estéticas com a categoria do "Gosto", pois a Razão prescindia de uma faculdade caracterizada como primordialmente sensível, corporal, terrena, profana, ou pior, incomunicável. Tais preceitos são relevantes por que indicam um ajuste na formação humana em detrimento da dimensão sensível.

Gadamer (1998, p. 82) aborda bem como se operou a mudança estatutária da questão do "Gosto", em que o mesmo proporcionou a passagem de uma concepção de um Belo tratado sob uma perspectiva inicialmente moral para um âmbito mais propriamente estético. Para o supracitado filósofo, o "Gosto", concebido inicialmente como categoria moral, funcionava como elemento propulsor para um ideal de humanidade, para uma humanidade canonizada. Fora do "Gosto" canonizado da época, havia o afastamento dos ideais humanos aceitáveis para o momento.

$\mathrm{Na}$ Antiguidade Clássica, perseguiam-se cânones matemáticos e afastar-se dos mesmos significava ser enquadrado entre os "bárbaros". Na Idade Média, têm-se critérios teológicos e se distanciar destes significava mergulhar em heresias, se caracterizar como anticristão. No Renascimento, havia critérios científicos, cuja contraposição seria o status da ignorância, do erro. E a partir do século XVII, havia critérios da Racionalidade Moderna, critérios estes que perduraram também pelo século XVIII, cujo distanciamento significava ficar afastado das coisas sérias da Razão, para sucumbir à ingenuidade e puerilidade, em outras palavras, para perder-se com distrações estéticas, meros joguetes da imaginação.

A partir da Modernidade, século XVII em diante, emergiram duas vertentes sobre o Belo e consequentes repercussões à forma de tratar o "Gosto". Uma de orientação objetivista e a outra, de orientação subjetivista. Pela corrente objetivista, conforme ressalta Bastos (1986, p. 6-29), destacam-se Boileau e Baumgarten. Os referidos pensadores consideravam a possibilidade de racionalizar as questões atinentes ao Belo. O primeiro considerava que a Arte deveria voltar-se para um critério racional, em especial o da verossimilhança, do universal, do essencial, em que o Belo pudesse aproximar-se da verdade, sem prender-se ao objeto particular e concreto em que estivesse representado. O segundo porque concebia a Estética como uma gnoseologia, ainda que de caráter inferior e obscura.

Pela vertente subjetivista, consoante asseverado por Bastos (1986, p. 26), merece destaque a influência de Descartes, para quem o fenômeno estético da beleza, como produto da imaginação, não poderia ser racionalizada. 


\section{A DELICADEZA DO GOSTO | Josivan Moura de Sá e Almir Ferreira da Silva Júnior}

A partir dessas orientações, o "Gosto" torna-se vinculado à imaginação, e esta subjugada à Razão. Com isso, as questões estéticas passaram a ser vistas como passatempo da imaginação para divertimento da Razão, que mais cedo ou mais tarde deveriam ceder espaço para as "coisas sérias" do entendimento.

Em todo caso, na forma como era concebido nas supracitadas épocas, ao "Gosto" transparecia um sério problema: se o ser humano era dotado da faculdade racional, teológica, científica, apropriada para tratar das verdades exatas, metafísicas e das coisas sérias da Ciência, por que preocupar-se com uma faculdade que só consegue aproximar-se de aspectos sensíveis, mutáveis, imperfeitos? Em um cenário como este, não era possível ao "Gosto" competir à altura com a Razão, fazendo com que este fosse concebido como questão menor na Filosofia. Talvez, a maior preocupação filosófica consistisse em investigar o porquê da ocupação com questões tão "mínimas".

Não obstante às disputas estéticas da época (subjetivistas versus objetivistas), Baltasar Gracián, padre jesuíta espanhol, ainda no século XVII, em um brilhante apólogo encontrado na obra "Agudeza e Arte de Engenho", de sua autoria, mostrava-se não só ciente do referido duelo, com também apontou para novos rumos que a questão do "Gosto", até então menosprezada, poderia ser redirecionada, muito embora Gadamer (1998, p. 83) evidencie que o mencionado jesuíta ainda esteja vinculado a um ideal de humanidade.

Em todo caso, no apólogo supracitado, que só não vai aqui citado na íntegra devido à sua extensão, observa-se a imagem da tiranização do "Gosto", que remete à crítica à vinculação do mesmo a cânones determinados, além do que o "Gosto" é elevado à condição de Rei das Potências, confrontando diretamente a importância que se atribuía à Razão, considerada, até então, como a engrenagem motora do mundo. Vale ressaltar ainda a presença da concepção de Arte como meio de expressão de verdade, não atrelada aos moldes científico-objetivistas.

Não obstante, foi no século XVIII que a questão do Gosto se consolidou como um problema eminentemente filosófico (MORA, 2005, p. 1228). É nesse contexto que se insere o pensamento humeano.

Foi com o filósofo David Hume que a mensagem do padre jesuíta Baltasar Gracián parece ter sido melhor captada. O filósofo escocês parece ter percebido que a questão do "Gosto", ainda não havia recebido a abordagem adequada até então. A abordagem humeana apontou para a possibilidade de o referido conceito assumir um estatuto diverso do que lhe era conferido até aquele momento, deslocando-o para primeiro plano, de tal forma que se mostrou capaz de abalar relações outrora pensadas como incontestáveis.

A iniciativa humeana é atestada por Bayer (2000, p. 255), para quem David Hume foi o primeiro a levantar filosoficamente o problema do "Gosto" ao posicioná-lo como fenômeno do sentimento, direcionando a discussão estética para um caminho que suplantaria aquelas vertentes vigentes em sua época. Com o pensamento humeano, as correntes subjetivistas e objetivistas modernas passaram a ser objeto de críticas consistentes. As críticas humeanas foram de tal magnitude que se mostraram capazes de operar verdadeira desestabilização dos pilares científicos e metafísicos da época, a exemplo da questão da verdade.

Hume opera um deslocamento da verdade para a instância do sentimento do Belo, deslocamento este que será de fundamental importância para as discussões modernas e contemporâneas acerca da relação entre Arte e verdade.

A verdade proporcionada pelo sentimento do Belo, no entanto, não se funda mais em uma esfera extra-sensorial, científica, teológica, nem se trata de uma brincadeira pueril da imaginação. Trata-se de uma verdade que se materializa no plano da empiria estética, tendo a faculdade do "Gosto" como a principal operadora da verdade, sem a pretensão de esgotá-la em uma exatidão quer seja matemática, científica ou religiosa, podendo o Belo apresentar-se não mais aprisionado a cânones específicos, mas mostrar-se em toda sua vivacidade e multiplicidade empírica. 


\section{A DELICADEZA DO GOSTO | Josivan Moura de Sá e Almir Ferreira da Silva Júnior}

O "Gosto", ao requerer o patamar da verdade, sem apresar-se a cânones, pôde desvincular-se da esfera moral, posicionando-se, por sua vez, na seara da Estética propriamente dita. Abriam-se, com isso, amplas portas para as mais diversas formas de expressões artísticas, muito embora tais manifestações tardassem um século para surgirem, além de muitas vezes ainda rivalizarem entre si, como a querer monopolizar o acesso ao sentimento do Belo.

É neste sentido que se deve compreender, conforme sustenta Gadamer (1998, p. 82), a forma como a questão do "Gosto" alterou seu estatuto filosófico, ou seja, passando da esfera moral para situar-se na instância propriamente estética. Transição esta que, no entanto, não se deu de maneira simples e fácil, pois as concepções objetivistas e subjetivistas ainda eram plenamente vigentes na época em que vivera Hume. Em todo caso, facultou-se ao "Gosto" não seguir mais os caminhos da objetividade tradicional, nem a se conceber como vinculado a atividades ilusórias (não sérias).

Observa-se, dessa forma, que o "Gosto", a partir do século XVIII, em especial com o pensamento de David Hume, pôde se configurar como autêntico problema filosófico. Sua particularidade desponta a partir de sua proposta nova, qual seja, e buscar e fixar um padrão para o gosto, uma questão estético-educacional a ser desenvolvida.

A referida questão passou a exigir novas reflexões acerca da relação entre Belo, Arte e Verdade, abrindo espaço para o debate referente à autonomia da Arte e a importância da dimensão estética na formação humana e como agente de transformação social.

Todavia, se o "Gosto", a partir de então, se configurava como instância da verdade, os objetos sujeitos a sua apreciação poderiam estar justificados como expressão de verdade? Em melhores palavras, qualquer objeto apreciado como uma obra de Arte, expressão do sentimento do Belo, expressaria uma relação de verdade, conforme se constituísse em objeto de agrado de qualquer sujeito? E ainda, os objetos condenados pelos padrões canônicos das mais variadas épocas não possuiriam valor algum como Arte, ou seja, não proporcionariam a experiência do Belo? Tais foram os problemas que Hume se propôs a enfrentar com sua teoria do "Padrão do Gosto".

\section{3 | O PADRÃO DO GOSTO EM HUME}

David Hume é tradicionalmente associado a uma defesa cética no tocante a possibilidade epistemológica do conhecimento, muito embora haja alguma controvérsia a esse respeito, consoante explicita Smith (1995, p. 13). Não obstante, com base nessa interpretação, se poderia esperar um posicionamento cético do referido filósofo quanto à questão do Gosto, haja vista que o próprio Hume (1973, p. 315) constata a existência de uma variabilidade de gostos: "É demasiado óbvia para deixar de ser notada por todos, a extrema variedade de gostos que há no mundo, assim como de opiniões."

Entretanto, a resposta humeana para o problema acima advém sob a forma de uma busca pelo "Padrão do Gosto", que, consoante palavras do próprio filósofo escocês (1973, p. 316), "É natural que procuremos encontrar um padrão do gosto, uma regra capaz de conciliar as diversas opiniões dos homens, pelo menos uma decisão reconhecida, aprovando uma opinião e condenando outra."

Uma leitura desatenta da definição apresentada acima desemboca facilmente em um equívoco, haja vista que remete à ideia de que o "Padrão do Gosto" humeano seria uma referência a uma tábua de normas para apreciação artística em geral.

O mencionado equívoco se deve ao fato de que o termo "padrão" se encontra vinculado a vários sentidos usuais. Um deles, por exemplo, está relacionado à atividade de estamparia, considerando esta como uma imagem utilizada para obtenção de várias cópias iguais ao modelo. Outro sentido usual diz respeito à interpretação do termo "padrão" atrelado aos significados de "norma", "regra", "cânon". Tais sentidos quando associados ao sentido de "gosto" remetem para a falsa ideia de que Hume estaria propondo uma padronização de gostos, segundo determinadas regras estéticas. 


\section{A DELICADEZA DO GOSTO | Josivan Moura de Sá e Almir Ferreira da Silva Júnior}

O equívoco se desfaz ao se analisar mais detalhadamente os conceitos de regra, cânon ou norma no âmbito da Estética. Tais expressões remetem a um "como fazer" e o "que expressar" na arte, o que remete ao conceito de poética, definido por Pareyson (1997, p. 11), consoante citação a seguir:

A poética é programa de arte, declarado num manifesto, numa retórica ou mesmo implícito no próprio exercício da atividade artística; ela traduz em termos normativos e operativos um determinado gosto, que, por sua vez, é toda a espiritualidade de uma pessoa ou de uma época projetada no campo da arte.

Com base na definição acima, observa-se que uma poética é um conjunto normativo determinado para a expressão artística no que toca às regras, aos cânones adotados, ou seja, não comporta abertura, flexibilidade aos diversos "como fazer" da Arte. Uma poética busca distanciar-se de suas "rivais" e só excepcionalmente mantém contato com outras.

Contudo, na obra "Do Padrão do Gosto", de David Hume, não é possível encontrar regras de "como fazer" ou "como expressar" o Belo. Em hipótese alguma Hume promove a exclusão de uma determinada poética em prejuízo de outra. Ao contrário, a proposta do mencionado filósofo abrange as mais diversas poéticas, no intuito de conciliá-las em sua multiplicidade de gostos.

Hume sabe que a aludida tarefa conciliatória é marcada por certa dificuldade, haja vista a existência de poéticas até contrárias entre si. Entretanto, o referido filósofo logra êxito em sua busca pelo "Padrão do Gosto" ao evidenciar que as mais variadas expressões artísticas autênticas encerram uma relação de verdade, capaz de respeitar a diversidade das mesmas e ser comunicada a todos os sujeitos de maneira consensual.

Todavia, esse caráter conciliatório do "Padrão do Gosto" humeano não significa que todos os gostos devam ser colocados em mesmo plano de consideração, pois não se pode olvidar que o filósofo se utiliza da expressão "aprovando uma opinião e condenando outra." Nesta passagem, talvez, se encontre um dos motivos justificadores da vinculação da proposta humeana à ideia de uma poética disfarçada, cujos contornos são apenas mais genéricos do que as demais.

Entretanto, a terminologia "poética geral" consiste em expressão que não parece se aplicar bem ao pensamento humeano, tendo em vista que uma poética possui regramentos bem delimitados, não amparando elementos divergentes, consoante já se viu acima na definição de Pareyson. Além de que, as poéticas, não raras vezes, rivalizam entre si no que se refere aos seus modos de expressão, de operação artística, ao tempo em que o "Padrão do Gosto", dispensando tais regras, vai buscar em todas as poéticas um ponto universal, amplamente conciliatório, sem obrigá-las a se desfazerem de seus elementos característicos.

Vale ressaltar, que neste quesito específico, já é possível perceber o afastamento do pensamento humeano da vertente objetivista tradicional, haja vista que o mencionado filósofo não promove a fixação de um critério de exatidão para apreciação estética, conforme se pode depreender das palavras seguintes:

Eliminar as investidas da imaginação, reduzindo toda expressão a uma verdade e uma exatidão geométricas, seria inteiramente contrário às leis da crítica. Porque o resultado seria a produção do tipo de obra que a experiência universal mostrou ser o mais insípido e desagradável. (HUME, 1973, p. 317).

Dessa forma, não é possível atrelar a concepção humeana de "Padrão do Gosto" às significações usuais dos termos que o compõem. Por não se tratar de uma poética, não há como vincular o referido "padrão" a uma proposta de formatação industrial artística, tal como as atividades de estamparia. 


\section{A DELICADEZA DO GOSTO | Josivan Moura de Sá e Almir Ferreira da Silva Júnior}

Todavia, há ainda outro equívoco em relação ao pensamento humeano, de igual importância e gravidade que o acima indicado. O mesmo consiste na versão de que Hume estaria promovendo uma aristocratização estética (uma elitização), em que poucos seriam os responsáveis pelo "Padrão do Gosto". A objeção é notória ao pensamento humeano: não há situação mais desconfortável do que o fato de se ter os gostos homogeneizados e determinados por outrem.

Um filósofo de renome a defender o referido equívoco foi o francês Luc Ferry (1994, p. 91), consoante se depreende da seguinte citação: "[...] a reflexão de Hume o leva a assentar de direito o valor universal de um 'bom gosto' que tende a se concentrar, em última instância, numa aristocracia estética." Segundo o filósofo francês (FERRY, 1994, p. 94), o "Padrão do Gosto" seria uma teoria fadada ao colapso, assim que a variabilidade de gostos se inserisse entre os membros dessa própria elite.

O segundo equívoco acima se deve ao fato de que Hume parece se referir a um número reduzido de sujeitos, que seriam os responsáveis pelo "padrão". Evidentemente, há vários momentos na obra "Do Padrão do Gosto", em que ocorre a menção à figura de "homens raros", a exemplo do que se segue: "[...] acontece que o verdadeiro juiz das belas artes, mesmo nas épocas mais cultas, seja uma personalidade rara" e, "[...] alguns homens em geral, por mais difícil que seja identificá-los rigorosamente, devem ser reconhecidos pela opinião universal como merecedores de preferência, acima dos outros" Hume (1973, p. 322); sendo, portanto, factível, a interpretação no sentido de existência de um número limitado desses mencionados sujeitos, como que a formarem uma elite do Belo.

Tal equívoco pode ser desfeito interpretando-se a figura desses "homens raros" humeanos como sendo uma figura de valor retórico utilizada para realçar o caráter de elevação e estimabilidade do sentimento do Belo. Essa figura erige-se em um muro de dificuldades, à pretensão dos eventuais usurpadores dessa posição de raridade, uma vez que se exige o distanciamento das particularidades às quais os sujeitos estão atrelados, particularidades estas que, muitas vezes, os conduzem a discórdias intermináveis, consoante reforço das seguintes palavras:

\footnotetext{
Se uma determinada pessoa é ou não dotada de bom senso e delicadeza de imaginação, livre de preconceitos, é coisa que pode muitas vezes dar motivos a disputa, e está sujeita a muita discussão e investigação. Mas que essa personalidade é valiosa e estimável é coisa que ninguém pode deixar de concordar. (HUME, 1973, p. 322).
}

Vale frisar que a imagem de "homens raros" não está provida de um valor conceitual tal como se estivesse em um tratado sistemático filosófico, mas está investida de um "colorido da imaginação" (HUME, 1973, p. 321), inserto na estrutura de um ensaio literário, passível, portanto, dos floreios poéticos, bem característicos ao estilo ensaístico do "Século das Luzes", cujas estruturas não se obrigavam aos rigores conceituais exigidos aos tratados da época.

Hume se utiliza desses "homens raros" apenas para fazer referência que, em relação ao sentimento do Belo, não é cabível a elevação do gosto particularizado de um indivíduo (ou mesmo de um determinado grupo) à instância de universalidade. Com isso, exige-se a não confusão entre o Belo e o agradável, o que não implica que os indivíduos devam abandonar a esfera da agradabilidade (fato talvez até impossível de ocorrer). O que se espera é apenas eliminar a arrogância dos pretensos "juízes" que querem, a todo modo (condenação ao ostracismo ou envenenamento, fogueira, forca, dentre outras formas), impor seus gostos, fazer prevalecer suas particularidades como as únicas possíveis.

David Hume, com sua proposta de "Padrão do Gosto", a partir desses "homens raros", não está advogando a ideia de uma de uma humanidade canonizada. Ao contrário, sua proposta opera o abandono de tal ideia, para que o homem possa mostrar-se em toda sua multiplicidade, desenvolvendo sentimentos. 
A proposta humeana se configura, assim, mais como uma restrição aos pretensos críticos que não poupam esforços em absolutizar seus gostos. O "Padrão do Gosto" não se trata de alguma tábua de valores estéticos para disputa. Se eventuais indivíduos passam a disputar sobre aquilo que lhes é mais agradável ou não é porque já estão destituídos daquele padrão.

Observa-se que a crítica luc-ferryana, não se sustenta. Reconhece-se que elevar o que é agradável à categoria de Belo não se distanciaria muito do estabelecimento de uma monarquia do "Gosto", ou mesmo ditadura do agradável (e por que não do descartável?). Entretanto, conforme já evidenciado não é este o intento de Hume.

Com a descaracterização desses equívocos, em relação à concepção humeana de "Padrão do Gosto", observa-se que Hume distancia-se da concepção objetivista tradicional. Todavia, no "Século das Luzes" ainda havia outro sério empecilho ao pensamento do filósofo. Tratava-se da concepção subjetivista do Belo.

A vertente subjetivista fundamentava-se, basicamente, em duas teses que dificultavam a percepção de qualquer possibilidade de estabelecer o "Padrão do Gosto". A primeira fazia referência à distinção entre julgamento e sentimento. A segunda, derivada da primeira, tratava-se da equivalência dos gostos. Tais ideias eram amplamente aceitas na época. A proposta humeana opôs-se a essas teses, porém seguiu todo um roteiro especial.

Em relação à primeira tese, há concordância parcial de Hume. Admite haver distinção entre julgamento e sentimento, posto que a verdade do primeiro é de natureza distinta à do segundo. Contudo, promove uma inversão em relação à importância dos mesmos, ou seja, para o referido filósofo (HUME, 1973, p. 322), o sentimento assume maior importância em relação ao julgamento, haja vista que o primeiro consegue obter êxito no estabelecimento da verdade que lhe é própria, enquanto que o segundo constantemente se vê obrigado a substituir as suas verdades por outras.

Já é possível antecipar as consequências dessa inversão promovida por Hume. O "Gosto" passa, agora, a exigir o poder de "desvelador da verdade". Os objetos da imaginação não precisam mais ser encarados como simples joguetes para a alegria da Razão.

A segunda tese, contudo, ainda perdura, uma vez que é possível aos gostos se estabelecerem relações de verdade, o que impossibilitaria o estabelecimento de alguma hierarquização e alguma separação entre os mesmos, tornando destituída de sentido a distinção entre Belo e agradável, já que passariam a ser conceitos dotados de mesmo peso estético.

Entretanto, em relação à segunda tese, Hume (1973, p. 317) não descarta a possibilidade de que os gostos possam ter alguma equivalência, chegando a admitir um "princípio da natural igualdade dos gostos." Ressalte-se, porém, que não se trata de uma equivalência científica, como se estivessem em jogo quantidades auferíveis, o que poderia abrir margem para a concepção de um gosto homogeneizado, que já se evidenciou tratar-se de equívoco.

No pensamento humeano, os gostos são equiparáveis apenas sob certas circunstâncias. Não é possível a comparação entre objetos desproporcionais, pois segundo Hume (1973, p. 317), trata-se de "um evidente absurdo, quando se comparam objetos tão desproporcionados."

Vale lembrar que a equivalência não se refere aos objetos representados, o que apontaria apenas para os elementos agradáveis. No pensamento humeano, a alusão que se faz é aos sentimentos estéticos propriamente ditos, ou seja, ao sentimento do Belo, haja vista que os objetos estéticos estão ligados ao eu, conforme pensa o filósofo: "A beleza ou deformidade está intimamente ligada ao eu, objeto destas duas paixões" (HUME, 2001, p. 352-353).

Para Hume (1973, p. 317), a saída desse problema consiste em perceber que há uma diferenciação entre os homens no que se refere às suas capacidades apreciativas, uma vez que estas que são passíveis de serem abaladas pela mais variadas circunstâncias, conforme se depreende das seguintes palavras: 


\begin{abstract}
[...] não devemos supor que, em todos os casos, os homens sintam de maneira conforme a essas regras. Estas emoções mais sutis do espírito são de natureza extremamente delicada e frágil, e precisam do concurso de grande número de circunstâncias favoráveis para fazê-las funcionar de maneira fácil e exata [...]. O menor dano exterior causado a essas pequenas molas, ou a menor desordem interna, é o bastante para perturbar seu movimento, e confundir a operação do mecanismo inteiro.
\end{abstract}

Dessa forma, é possível que algumas "gustações" não estabeleçam relação com o sentimento do Belo, mas meramente com o agradável, não se estabelecendo a relação de consenso, motivo pelo qual, assevera Hume (1973, p. 322), "[...] não é possível pôr no mesmo pé o gosto de todos os indivíduos [...]", sem que se tenha como referência um autêntico "Padrão do Gosto".

Percebe-se que Hume, ao contrapor as teses subjetivistas, suplanta as dificuldades impostas pela mencionada corrente de pensamento. Neste sentido, as questões do "Gosto" abriram-se à discussão. Primeiro, porque ao se evidenciar que o "sentimento" assegura a expressão de verdades mais duradouras do que as do "entendimento"; segundo, porque evidencia que os gostos são passíveis de distinção, consoante estabeleçam ou não uma relação autêntica com o sentimento do Belo, ou seja, não são mais equivalentes em caráter absoluto. Por sua vez, a vertente objetivista teve um de seus principais fundamentos desestabilizados, vendo-se obrigada a ceder para a esfera do sentimento (ou pelo menos o compartilhamento com este) os direitos tutelares e exclusivos acerca da verdade.

Evidencia-se, assim, que a busca pelo "Padrão do Gosto", na estética de David Hume, não se trata de empreitada impossível, haja vista que o filósofo conseguiu apresentar respostas consistentes aos problemas decorrentes das correntes objetivistas e subjetivistas estéticas. Contudo, a promoção do sentimento às instâncias da verdade, no pensamento humeano, não ocorre de maneira tácita, antes requer uma delicadeza especial para o sentimento do Belo, a fim de evitar a queda do "Gosto" na mera agradabilidade e nos desejos obscuros de tiranização estética. Convém assim, a investigação acerca dessa delicadeza.

\title{
4 | A DELICADEZA DO GOSTO
}

Com o "Padrão do Gosto" Hume objetiva fazer a separação entre a experiência do Belo e a experiência meramente agradável. Para tanto, destaca a necessidade de que os sujeitos sejam dotados de uma capacidade apropriada para tal fim. Trata-se da "Delicadeza do Gosto", que se constituirá como fundamento nada homogeneizador ao supracitado "padrão".

No pensamento humeano, a "Delicadeza do Gosto" não se caracteriza como uma simples capacidade sensorial de precisão para a apreciação do Belo, adstrita a alguns poucos sujeitos, constituintes de uma elite estética. Ao contrário, com a referida delicadeza, a questão do Belo ultrapassa os limites que circunscrevem a mera agradabilidade (individual ou aristocrática), já que é por meio dela que o indivíduo pode compreender a pluralidade contemplativa a que o Belo se propõe, não se restringindo às meras percepções agradáveis dos sujeitos (ou de um restrito grupo destes apenas), mas à universalidade de todos os indivíduos, na medida em que seus gostos se mostram abertos ao consenso.

No ensaio "Da Delicadeza do Gosto e da Paixão", Hume (2004, p. 96) apresenta uma imagem da "Delicadeza do Gosto", contrariamente a uma certa "Delicadeza da Paixão", conforme se depreende das palavras abaixo: 


\title{
A DELICADEZA DO GOSTO | Josivan Moura de Sá e Almir Ferreira da Silva Júnior
}

\begin{abstract}
Existe uma delicadeza do gosto [...], que se assemelha muito a essa delicadeza da paixão, e produz a mesma sensibilidade em relação aos diversos tipos de beleza e deformidade que aquela produz em relação à prosperidade e à adversidade, aos favores e às injúrias. Quando você mostra um poema ou uma pintura a um homem dotado desse talento, a delicadeza de seu sentimento faz com que ele seja sensivelmente tocado por cada detalhe; as qualidades da obra não podem ser apreciadas com mais prazer e contentamento, nem com mais desgosto e desconforto os seus eventuais absurdos ou negligências.
\end{abstract}

Consoante pensa Hume (2004, p. 97-98), a “Delicadeza do Gosto" se caracteriza por ser desejável pelos indivíduos em geral, em detrimento da "Delicadeza da Paixão". A primeira se evidencia como uma abertura aos sentimentos proporcionados pelos prazeres mais elevados e refinados, enquanto que a segunda promove o desvirtuamento da contemplação dos aludidos prazeres. $\mathrm{O}$ indivíduo detentor da primeira capacidade está mais apto a escapar dos eventuais desvios que seus apetites promovem, isto é, torna-se menos propenso à confusão entre os juízos agradáveis e juízos estéticos autênticos.

Para Hume (2004, p. 100), o aludido talento consiste em ampliação perceptiva para os sentimentos mais delicados e elevados, comparativamente aos relógios de parede, consoante se vê nas palavras a seguir: "[...] a um relógio de parede ou pulso, no qual a máquina mais simples basta para dizer as horas; porém só as mais refinadas podem indicar os minutos e os segundos, e distinguir as menores diferenças de tempo."

Também há uma anedota, narrada por Hume em seu ensaio "Do Padrão do Gosto", extraída da obra "Dom Quixote", que reforça a imagem do que seja a "Delicadeza do Gosto". Trata-se do episódio de Sancho Pança e seus parentes apreciadores de vinho, que vai abaixo reproduzida:

Dois meus parentes foram uma vez chamados a dar sua opinião sobre um barril de vinho [...]. Um deles prova o vinho, examina-o, e depois de madura reflexão declara que ele seria bom, não fora um ligeiro gosto a couro que nele encontrava. O outro, depois de empregar as mesmas precauções, dá também um veredicto favorável ao vinho, com a única reserva de um sabor a ferro que facilmente podia nele distinguir. Não podes imaginar como ambos foram ridicularizados por seu juízo. Mas quem riu por último? Ao esvaziar o barril, achouse no fundo uma velha chave com uma correia de couro amarrada. (HUME, 1973, p. 318).

Torna-se importante ressaltar que a comparação aos relógios e o episódio de Sancho Pança acima narrados podem conduzir a um equívoco, para o qual merece alerta. Trata-se de compreender a "Delicadeza do Gosto", no pensamento de Hume, tendo como referência a capacidade meramente sensorial especializada a ponto de captar as mínimas sutilezas que a contemplação estética pode proporcionar. Tal equívoco se desfaz tão logo se dê atenção à advertência de que há casos em que é até possível a existência de uma capacidade sensorial de precisão, porém nem sempre ela conduz à experiência do Belo (HUME, 1973, p. 319).

Com efeito, para Hume (1973, p. 317), a "Delicadeza do Gosto" é um talento apurado que os sujeitos devem dispor para apreciação autêntica do Belo, capacidade esta, no entanto, facilmente abalável pelos mais diversos meios de interferência, com sérios prejuízos para a experiência estética, conforme fiquem afetadas as condições externas ou internas ao sujeito (momento, lugar, imaginação, serenidade espiritual, concentração do pensamento, atenção destinada ao objeto, dentre outras).

Entretanto, conforme pensamento humeano, a mencionada delicadeza não se trata de uma capacidade sensorial, mas de uma capacidade que relaciona entendimento (razão) e sentimento (gosto), tal como se depreende da seguinte citação: "[...] a razão, se não é uma parte essencial do gosto, é pelo menos necessária para as operações desta última faculdade" (HUME, 1973, p. 321).

Percebe-se, em Hume, que o termo delicadeza pode ser remetido ao sentido usual de fragilidade, de debilidade, suavidade, brandura, em que algo pode ser facilmente abalado por circuns- 
tâncias diversas (externas ou internas ao sujeito). Não obstante, ainda é possível perceber a associação do referido termo a outros dois sentidos. Primeiramente, ao de um senso apurado do espírito. Em segundo lugar, ao de uma fragilidade, não de uma capacidade (talento) apenas, mas da própria natureza humana.

Em relação ao sentido de "senso apurado do espírito", no pensamento humeano, considera-se aquele que se adquire com a prática e contemplação constante dos objetos que se propõem à experiência estética. Para Hume (1973, p. 319-320), a "Delicadeza do Gosto" depende, assim, da constância do exercício contemplativo das obras artísticas, sem o que ocorre uma apreciação superficial, vacilante, obscura.

Segundo Hume (1973, p. 320), essa constância apreciativa aprimora o espírito, colocando-o em condições de adentrar na esfera do sentimento do Belo, proporcionado pela obra em contemplação, contribuindo para tanto a percepção das técnicas utilizadas, das ideias representadas, dos sentimentos e pensamentos que faz aflorar que vão se acumulando nas apreciações estéticas, colocando o sujeito nas condições adequadas para posicionar a obra apreciada em seu devido lugar (o espaço da genialidade).

Vale ressaltar, porém, que o exercício acima, não se trata de uma tarefa científica (dissecativa) da obra de arte, pois como já se viu a concepção objetivista fora deixada para trás, já que não se busca a coleta de caracteres do objeto contemplado, mas do sentimento que o mesmo proporciona, pois não se pode olvidar que "[...] a beleza e a deformidade [...] não são qualidades dos objetos [...]" (HUME, 1973, p. 318-319).

Quanto ao sentido de "fragilidade da natureza humana", no pensamento de Hume, considera-se o fato desta natureza ficar suscetível às interferências que podem embotar o "Gosto", ocasionando a obnubilação da experiência consensual do belo.

Para Hume (1973, p. 321), o belo é um sentimento que requer a consensualidade, ou seja, não se trata de uma experiência particular. Não traz em seu íntimo a marca egocêntrica da agradabilidade, mas a do consenso. Consenso, aqui mencionado, não no sentido de algo atingido pela disputa, mas no sentido universal, que possa circunscrever a gama plural de indivíduos em torno de um denominador comum e, ao mesmo tempo, abrangente, sem reduzi-los a uma fórmula única e homogênea: "[...] devo distanciar-me dessa situação e, considerando-me a mim mesmo como um homem em geral, fazer o possível por esquecer meu ser individual e minhas circunstâncias peculiares."

Vislumbra-se, no fragmento acima, o que se poderia denominar de "imperativo humeano" inerente ao sentimento do belo: contemplas de tal forma que em teu gosto seja levado em consideração o consenso humano. Exige-se, com a "Delicadeza do Gosto", que o sujeito se coloque na condição de sujeito universal, sem a pretensão de subjugação do gosto dos demais.

Neste sentido, no pensamento humeano, o belo é a abertura consensual para a convivência dos indivíduos, sem a aniquilação da diversidade com que o referido sentimento pode se manifestar entre os homens. É a condição para que ainda possam se perceber como participantes de uma natureza humana, marcada pela abertura e multiplicidade para a comunicação do sentimento do belo, ou seja, é a condição para os sujeitos se fazerem presentes aos demais, sem necessidade de sobrepujar os gostos dos mesmos por meio de uma régua valorativa de cânones (científicos, divertidos ou soteriológicos). Em síntese, é a via, por intermédio da qual, aos sujeitos é possível se lançarem à multiplicidade das experiências humanas.

Qualquer prejuízo ao sentimento do belo acarreta, por consequência, sérios prejuízos à natureza humana, já que ficam diminuídas (ou mesmo excluídas) as possibilidades de compreensão da abertura e pluralidade da natureza humana, ou seja, se ocorre o embotamento da "Delicadeza do Gosto", a contemplação do belo fica prejudicada e, consequentemente, a própria natureza humana, pois os indivíduos perdem a conexão com os "[...] mais finos e inocentes prazeres de que é 
é suscetível a natureza humana" (HUME, 1973, p. 319), ficando suscetíveis, na melhor das hipóteses, ao estabelecimento do aprisionamento às relações meramente agradáveis, com o agravante de almejarem a subjugação dos gostos dos demais.

Observa-se que o consenso proporcionado pelo sentimento do belo afasta qualquer vinculação da estética humeana ao ditado popular "Gosto não se discute". Este se aplica mais à esfera da agradabilidade. Hume (1973, p. 316) afirma que o que agrada a um sujeito não agrada a outro e mesmo no âmbito de um único sujeito a variação do agradável é possível de ocorrer.

Percebe-se que, no pensamento humeano, a "Delicadeza do Gosto" não se constitui como uma capacidade dissecativa à disposição do sujeito para o estabelecimento de experiências sensoriais. O sentimento do belo não deriva da captação da totalidade de nuances que um objeto pode permitir, posto que o mesmo não se caracteriza como um atestado de objetividade tradicional. Deriva, pois, da ligação consensual que se estabelece durante a contemplação da obra de arte. Característica esta sem a qual aquela totalidade não é suficiente para o afloramento do belo, talvez apenas o de uma experiência agradável (subjetivismo estético) ou "operação matemática" (objetivismo tradicional) ou experiência soteriológica dos objetos artísticos.

No pensamento humeano, dispor da "Delicadeza do Gosto" significa encontrar-se na condição pretendida pela obra de arte. Elevar-se a tal pretensão deve ser o objetivo da faculdade do "Gosto" para que possa perceber o afloramento do belo, o que significa que não será qualquer experiência que atingirá esse patamar, mas apenas aquelas abertas ao consenso. A obra de arte parece, assim, impor uma condição para sua adequada apreciação, conforme assevera Hume (1973, p. 320): "[...] a obra de arte [...] deve ser encarada de um determinado ponto de vista, e não pode ser plenamente apreciada por pessoas cuja situação [...] não seja conforme à que é exigida pela obra."

Todavia, segundo Hume (1973, p. 321), essa posição exigida pela obra é passível de ser afetada por um estado de espírito que torna o sujeito destituído da delicadeza necessária para a apreciação estética. Trata-se do estado de preconceito, pois "uma pessoa influenciada pelos preconceitos não preenche estas condições, persevera obstinadamente em sua posição natural, sem colocar-se naquele ponto de vista que é suposto pela obra."

Conforme assevera Hume (1973, p. 321), o preconceito é uma situação que impossibilita a contemplação estética, já que a mesma se descaracteriza, se corrompe, deixando o sujeito atrelado apenas à esfera do agradável, consoante se pode depreender das seguintes palavras "[...] não é menor o prejuízo que causa ao bom gosto, nem menor sua tendência para corromper o sentimento da beleza."

Julga-se ser este o fator essencial, no pensamento humeano, para o estabelecimento do "Padrão do Gosto", pois um sujeito capaz de uma delicadeza dessa magnitude, que possa superar seus preconceitos diante das mais variadas obras a serem apreciadas, conseguindo desprender-se das amarras da própria cultura, de seu próprio tempo, dentre inúmeras outras circunstâncias limitativas, poderá avaliar a obra de arte do ponto de vista adequado à mesma, sem receio de estar erigindo uma tábua de valores, uma régua canônica para os demais sujeitos.

Não se olvide que essa posição não se trata do abandono das circunstâncias íntimas do sujeito, mas de abrir-se à compreensão das mais variadas produções estéticas de outras culturas e outros tempos:

Se esta [a obra de arte] se dirige a pessoas de uma época ou de uma nação diferente, essa pessoa [o preconceituoso] [...] cheia dos costumes de sua própria época e seu próprio país, apressadamente condena o que parecia admirável aos olhos daqueles aos quais se destinava o discurso. [...] essa pessoa nunca conseguirá ampliar suficientemente sua compreensão [...]. É evidente que seu gosto não coincide com o verdadeiro padrão [...]. (HUME, 1973, p. 321). 


\section{A DELICADEZA DO GOSTO | Josivan Moura de Sá e Almir Ferreira da Silva Júnior}

Percebe-se que a "Delicadeza do Gosto" não se configura como um órgão sensorial de precisão para a apreciação estética. A referida delicadeza implica o posicionamento dos indivíduos no locus do sujeito universal, afastando-os da situação de preconceito, ou seja, permitindo-Ihes a abertura para a contemplação do resplandecer do sentimento do belo, cujo brilho evidencia a pluralidade da natureza humana, em sua diversidade de expressão.

\section{5 | CONSIDERAÇÕES FINAIS}

Diante das considerações expostas, faz-se necessário pontuarmos as seguintes questões: o que justifica a retomada de uma reflexão sobre o padrão do gosto e o sentimento de delicadeza, inerentes à natureza humana, como uma discussão relevante para pensarmos os fundamentos estéticos da educação? O que significa pensar a relação educação e gosto? É possível formar o gosto de alguém no propósito de educar ao sentimento do belo, à contemplação das artes, e consequentemente à pluralidade da natureza humana?

A dimensão estética da educação constitui-se como uma das temáticas nucleares acerca da natureza humana desenvolvidas no âmbito das ciências humanas e, de modo específico, a partir da filosofia moderna, ao privilegiar uma criteriosa reflexão acerca da subjetividade, seu paradigma central. Tradicionalmente nunca foi indiferente à problematização filosófica sobre a natureza humana a disposição dos seres humanos em seu exercício subjetivo, sentimental, contemplador e transfigurador da realidade natural imediata. Além de sensíveis, a nossa apreciação enquanto seres no mundo e a atribuição de sentido que conferimos às coisas, situações e fenômenos constituem elementos fundamentais em nossa formação e na construção de nossas identidades sócio-culturais. Assim, nos revelamos como seres dotados de gosto, cuja dinâmica ultrapassa a esfera de um subjetivismo isolado e nos coloca, interativamente, ante os nossos semelhantes.

Nesse sentido, as reflexões propostas por Hume são bastante relevantes. Mesmo não propondo a uma estética propriamente dita, suas reflexões, apoiadas em um método crítico, intentam promover não apenas a investigação sobre a natureza do gosto vislumbrando suas potencialidades e limites, mas destacar a importância em educá-lo, refiná-lo na perspectiva de experiências estéticas e cultivo do belo. Para tanto, faz-se necessária uma atenção especial ao conjunto de suas experiências, às suas práticas.

Embora seja inegável a variedade dos gostos, considerando o vasto número de seres humanos, disso não se pode concluir um relativismo incontornável do gosto ou mesmo desconsiderar a existência de padrões e comunidades de gosto estabelecidas pelas realidades cotidianas e sócio-culturais. Tal ponderação vale não apenas para justificar célebres artistas e referências de estilos estéticos que atravessaram o tempo, se tornaram clássicos na história das culturas e que são cultivados, até hoje, na formação dos povos, como também para nos fazer pensar o processo formativo e educacional da sensibilidade humana. Afinal, a formação estético-educacional dos seres humanos resulta de uma contextualização histórico-social e ético-politica do conjunto de experiências que cultivam padrões de gosto e, nessa perspectiva, desenvolvem uma identidade moral, estética e política e educacional.

A estética do gosto humeana não é solipsista, posto que pela imaginação e pela simpatia, princípios da natureza humana, o sentimento de prazer que a beleza nos proporciona nos desperta uma necessidade interativa e nos conduz aos outros, compartilhando, por vezes, uma uniformidade e um modo de pensar de um grupo ou mesmo de uma nação; simpatia enquanto um modo de reproduzir em nós o sentimento de um outro com o qual interagimos e nos relacionamos. Eis, por exemplo, o que diferencia o cultivo, em uma determinada época, de um tipo musical, de uma 


\section{A DELICADEZA DO GOSTO | Josivan Moura de Sá e Almir Ferreira da Silva Júnior}

nação para outra. É tal uniformidade promovida pela simpatia que muitas vezes é capaz de manter a identidade de caráter e do gosto de uma nação durante muito tempo.

Pensar a relação entre gosto e educação a partir das reflexões do filósofo escocês implica ressignificar essa faculdade em seu status tradicional de importância, na medida em que o mesmo esteve subjugado à razão. A formação do gosto, portanto, diz de uma faculdade que não está limitada a flutuações cambiantes e relativas de um sujeito isolado, apartado de suas interações, mas muito pelo contrário, sua reflexão remete a pensar uma pluralidade de sentidos, práticas de comportamentos e expressões sócio-artístico e culturais. Daí porque o pensamento de Hume ultrapassa uma vertente subjetivista sustentando que o gosto não se apresenta apenas como uma alegria da razão mas, sobretudo, como desvelador de uma verdade. Refleti-lo sob a perspectiva de um padrão - o padrão de gosto - nos reporta à inegável evidência de que, em todas as sociedades, a presença dos chamados homens e mulheres de gosto sempre definiram e sustentaram padrões e sentimentos de gosto, reguladores de uma época, e referenciais decisivos para transformações sócio-educacionais. Dessa forma, sustentar a importância dos padrões de gosto também significa não a imposição de uma particularidade, mas principalmente levar em conta a multiplicidade e o desenvolvimento de sentimentos.

O fenômeno do gosto enquanto objeto de discussão desenvolvida tem como base de sustentação a primazia do sentimento, base da reflexão estética e educacional. Afinal, a expressão de delicadeza do gosto e o belo apenas podem ser pensados após sentidos. Uma delicadeza para além de sua significação prosaica que nos remeta a uma simples fragilidade e brandura; não enquanto uma simples capacidade sensorial, mas como capacidade de captar sutilezas viabilizadas pelo exercício das experiências artísticas e estéticas. Daí porque essa abordagem filosófica, sobre o gosto destaca para esse sentimento um status de importância muito grande nas reflexões acerca da natureza humana recolocando a razão como referência de debate estético, porém agora destituída de um poder a priori diante dos próprios sentimentos.

Por fim, privilegiar uma discussão sobre estética e educação ancorada em uma filosofia da natureza humana que ressignifica a experiência do gosto e do sentimento de delicadeza como fenômenos sociais viabiliza a retomada de uma reflexão educacional ainda sempre aberta: em que medida a formação humana ainda está fixa a uma concepção de subjetividade direcionada por uma racionalidade que se sobrepõe a primazia da sensibilidade e ao cultivo dos sentimentos? E se atualizarmos a pergunta sobre quem educa: a razão ou o sentimento? No mínimo precisamos reconhecer que pensar a natureza humana sob a perspectiva de um padrão do gosto e de sua disposição à delicadeza significa admitir antes de tudo que o gosto é inerente ao sujeito universal e que em seu exercício os seres humanos não simplesmente contemplam suas singularidades, mas asseguram expressão de verdades e que são compartilhadas; verdades advindas da contemplação das artes e do belo. Por isso que pensar sobre o fenômeno do gosto também significa privilegiar a multiplicidade e o desenvolvimento de sentimentos que tecem as relações humanas e formam sua natureza. O gosto e a delicadeza dos seres humanos são radicalmente expressões subjetivas porque nos possibilitam partilhas e nos reinserem junto aos nossos semelhantes; nos educam e nos formam no mesmo horizonte que nos fazem ser com os outros. 
A DELICADEZA DO GOSTO | Josivan Moura de Sá e Almir Ferreira da Silva Júnior

\section{Referências}

BASTOS, F. J. de M. Panorama das idéias estéticas no Ocidente: do Renascimento a Kant. Brasília: Editora Universidade de Brasília, 1986. v. 2.

BAYER, R. História de la Estética. 8. reim. México: Fondo de Cultura Económica, 2000.

CASSIRER, E. A filosofia do lluminismo. Campinas: Editora da UNICAMP, 1997.

FERRY, L. Homo aestheticus: a invenção do gosto na era democrática. São Paulo: Ensaio, 1994.

GADAMER, H.-G. Verdade e método: traços fundamentais de uma hermenêutica filosófica. 2. ed. Petrópolis: Vozes, 1998.

GRACIÁN, B. Agudeza e arte do engenho. Tradução Christian Rocha. [16-]. Disponível em: <http://christianrocha.wordpress.com/2005/01/08/a-verdade-a-mentirae-a-agudeza/>. Acesso em: 19 nov. 2009.

HUME, D. Da delicadeza do gosto e da paixão. In: . Ensaios morais, políticos e literários. Rio de Janeiro: Topbooks, 2004.
. Do padrão do gosto. In: Ensaios morais, políticos e literários. São Paulo: Abril Cultural, 1973.

Tratado da Natureza Humana, Lisboa: Fundação Calouste Gulbenkian, 2001.

MORA, José Ferrater. Verbete Gosto, in: Dicionário de Filosofia, Tomo II (E-J), $2^{a}$ ed., São Paulo: Loyola, 2005.

OSBORNE, H. Estética e teoria da arte: uma introdução histórica. 3. ed. São Paulo: Cultrix, 1978.

PAREYSON, L. Os problemas da estética. São Paulo: Martins Fontes, 1997.

SÁ, J. M. de. A delicadeza do gosto em Hume. 2009. 57 f. Monografia (Graduação em Filosofia - Licenciatura) - Universidade Federal do Maranhão. São Luís, 2009.

SMITH, Plínio Junqueira. O Ceticismo de Hume. São Paulo: Loyola, 1995. 